\title{
An lodine Treatments Effect on Cell Proliferation Rates of Breast Cancer Cell Lines; In Vitro Study
}

\author{
Aisyah Elliyanti ${ }^{1,2 *}$, Veronica Y. Susilo ${ }^{3}$, Sri Setiyowati ${ }^{3}$, Pasupuleti Visweswara Rao ${ }^{4}$ \\ ${ }^{1}$ Medical Physics Department, Faculty of Medicine, Universitas Andalas. Kampus Limau Manis, Padang, West Sumatra, \\ Indonesia; ${ }^{2}$ Nuclear Medicine installation of the Radiology Department, Dr. M. Djamil Hospital, Padang, Indonesia; ${ }^{3}$ The Center \\ of Radioisotopes and Radiopharmaceuticals Technology, Badan Tenaga Nuklir Nasional, Puspitek Serpong, Tangerang \\ Selatan, Indonesia; ${ }^{4}$ Department of Biomedical Sciences and Therapeutics, Faculty of Medicine and Health Sciences, Universiti \\ Malaysia Sabah, Kota Kinabalu, Sabah, Malaysia
}

Abstract

Edited by: Ksenija Bogoeva-Kostovska Citation: Elliyanti A, Susilo VY, Setiyowati S, Rao PV. An lodine Treatments Effect on Cell Proliferation Rates of Breast Cancer Cell Lines; In Vitro Study. Open Access Maced J Med Sci. 2020 Nov 05; 8(B):1064-1070. https://doi. org/10.3889/oamjms.2020.5447 Keywords: Antineoplastic; Cell proliferation; Tumo progression; Cell lines; Breast cance *Correspondence: Aisyah Elliyanti, Medical Physic Department, Faculty of Medicine, Universitas Andalas. Indonesia. E-mail: aelliyanti@med unand ac id ORCID ID: 0000-0003-0812-8052. Received: $15-$ Sep-2020

Accepted: $26-$ Oct-2020
Copyright: $\odot 2020$ Aisyah Elliyanti, Veronica Y. Susilo, Sri Setiyowati, Pasupuleti Visweswara Rao Funding: This study was supported by a grant from Universitas Andalas, Padang, Indonesia research grant No: Competing Interests: The authors have declared that no competing interests Competing interests exist
under the terms of the Creative Commons AttributionNonCommercial 4.0 International License (CC BY-NC 4.0)
BACKGROUND: lodine can reduce breast tumor progression by mediates an antiproliferative effect.

AIM: This study aimed to investigate the effect of iodine (I2), Lugol (I3K), and the combination of both on cell proliferation of three different types of breast cancer cell lines.

METHODS: The samples were MCF7, SKBR3, and MDA-MB 213 cell lines. Cell proliferation rate was measured using colorimetric and clonogenic assays.

RESULTS: The cell proliferation rate of MDA-MB 231 cells was reduced significantly by treatment $\mathrm{I}_{2}, \mathrm{I}_{3} \mathrm{~K}$ and combination of both with $p=0.046, p=0.00$, and $p=0.00$, respectively. In MCF7 cells, $I_{2}$ reduced the cell proliferation of $54-94 \%$ and $\mathrm{I}_{3} \mathrm{~K}$ reduced the proliferation of $74-94 \%$. The effectiveness of $\mathrm{I}_{3} \mathrm{~K}$ treatments in slowing cell proliferation rate was dose-dependent. In SKBR3 cells, $\mathrm{I}_{2}$ reduced proliferation cell up to $85 \%$ and $\mathrm{I}_{3} \mathrm{~K} 4 \%-94 \%$ depending on the dose. Clonogenic assay results showed a discontinue of the cell proliferation by all doses of $\mathrm{I}_{2}$ and $\mathrm{I}_{3} \mathrm{~K}(10 \mu \mathrm{M}$ and $20 \mu \mathrm{M})$.

CONCLUSION: Breast cancer cell lines, representing subtypes of luminal A, HER2+, and triple-negative, show an excellent response to iodine treatments and $\mathrm{I}_{3} \mathrm{~K}$ response shows in a dose-dependent manner. Further studies are needed to investigate the effective in vivo doses.

\section{Introduction}

lodine plays a pivotal role in maintaining the mammary gland's normal healthy integrity and its deficiency transmutes a healthy structure and function of rat mammary gland [1], [2]. Some of the studies reported that iodine mediates apoptosis and has an effect on antineoplastic process [3], [4], [5]. lodine consumption of 3-6 mg/day has reduced breast hyperplasia, per lobular/ductal fibrosis, and slowing down breast cancer progression [6], [7]. lodine mediates antiproliferative effects directly or indirectly. Oxidized iodine eliminates the mitochondrial membrane potential (MMP) to mediate apoptosis directly or by forming iodolipids and activation of gamma type peroxisome proliferator-activated receptors $\gamma$ (PPAR $\gamma$ ) that trigger apoptosis [2], [5], [8], [9].

Cancer disease is the second leading cause of death globally; it caused more than ten million death annually [10], [11], [12]. The incidence rate of breast cancer in the United States (US) increased slightly by $0.3 \%$ per year, but the mortality rate declined by around $40 \%$ from 1989 to 2017 [13]. The Asian region has the lowest breast cancer mortality in the world [5]. Globocan report 2018 said that new breast cancer cases in the US are higher than in Japan (7.5\%:11\%) [12]. Seaweed is a common dietary component in Japanese and it is a rich source of iodine. Japanese iodine consumption is 25 times higher than in Western countries. It has been associated with the low incidence of breast cancer in Japanese people compared to Western [2]. However, breast cancer number in Japan continues to increase that may be exposed to the western diet and lifestyle [14].

Breast cancer was classified based on histopathology findings. Advanced techniques such as immunohistochemistry define the molecular subtypes based on the expression of estrogen receptor (ER), progesterone receptor (PR), and human epidermal growth factor receptor-2 positive (ERBB2/ HER2+) [15], [16], [17]. Identification of the molecular subtypes of breast cancer is essential for a personalized treatment plan and predict prognosis. Some breast cancer subtypes are resistant to some therapies [15], [17], [18]. Limitation of the benefit of available therapy challenges an emerge of new alternative therapy for breast cancer. 
The total amount of iodine in the human body is around $30-50 \mathrm{mg}$. Less than $30 \%$ presents in the thyroid gland. Around $60-80 \%$ is concentrated in extrathyroidal tissues. These include salivary glands, gastric mucosa, lactating mammary gland, the choroid plexus, and et cetera [1], [19]. Non-lactating breast tissue is known to be NIS and peroxidase poor and does not provide for organification [4].

$\mathrm{I}_{2}$ is taken up by a non-lactating mammary gland without the involvement of NIS and peroxidase activity, and it is a highly reactive species [2], [4], [20]. I mediates antiproliferative effect with direct or indirect action. In vitro studies showed that $\mathrm{I}_{2}$ exposure induced the mitochondria to release apoptosis factors that cause nuclear fragmentation directly [4], [21]. On the other hand, breast tumor tissues contain arachidonic acid (AA) more than the normal ones. lodination of AA formed 6-iodolactone (6-IL), which is an essential membrane lipid. PPAR $\gamma$ could be the mediator of the 6-IL apoptotic effect [1], [3], [5].

This study investigates the proliferation rates of $\mathrm{I}_{2}, \mathrm{I}_{3} \mathrm{~K}$, or a combination of both in various concentrations treatments of three types of breast cancer cell lines. It will obtain the potential extrathyroidal benefits of iodine and alternative breast cancer therapy.

\section{Materials and Methods}

\section{Cell lines and culturing}

This study uses three types of breast cancer cell lines MCF7 (estrogen and progesterone positive receptors/ER+ and $\mathrm{PR}+$ ) and SKBR3 (human epidermal growth factor receptor 2+/HER2+) and MDA-MB 231 (triple-negative) [18]. SKBR3 was purchased from the American Type Culture Collection, MCF7, and MDA-MB 231 cell lines were gifted from the Faculty of Medicine, Universitas Padjadjaran, Bandung-Indonesia. MCF7 and MDA-MB 231 cells were cultured in RPMI 1640 medium (Invitrogen). SKBR3 was cultured in McCoy's $5 \mathrm{~A}$ medium (Invitrogen). Mediums were added with $10 \%$ fetal bovine serum (Invitrogen), 1\% penicillin, 1\% streptomycin, and $1 \%$ amphotericin B. The cells were incubated at $37^{\circ} \mathrm{C}$ and supplied with $5 \%$ carbon dioxide $\left(\mathrm{CO}_{2}\right)$ until $90 \%$ confluence was reached.

\section{Proliferation rates}

The cells' proliferation rate was measured using a colorimetric assay and clonogenic test.

\section{Colorimetric assay}

Methyl thiazolyldiphenyl-tetrazolium bromide for iodine and Lugol and radioiodine treatments was used to measured cell proliferation rate. The cultured cells were washed with phosphate-buffered saline (PBS) twice, then seeded in a 96-well plate at a density of $\times 210^{4} /$ well and incubated for $24 \mathrm{~h}$ then treated with $1 \mu \mathrm{M}, 10 \mu \mathrm{M}, 20 \mu \mathrm{M}$ of $\mathrm{I}_{2}, \mathrm{I}_{3} \mathrm{~K}$, and a combination of $\mathrm{I}_{2}$ and $\mathrm{I}_{3} \mathrm{~K}$. The treatments were done for 24,48 , and $72 \mathrm{~h}$, and it carried out in triplicate. The control cells were treated with medium only. MTT (5 $\mathrm{mg} / \mathrm{ml}$ in PBS) was added to the wells, and the plate was incubated for $4 \mathrm{~h}$ at $37^{\circ} \mathrm{C}$. The medium was removed, and $100 \mathrm{ml}$ dimethyl sulfoxide was added to the wells, and the absorbance was measured at $550 \mathrm{~nm}$ using a colorimetric. equation:

The proliferation rate was calculated by the

Cell proliferation $(\%)=\frac{O D \text { test }-O D \text { blank }}{\text { OD control }-O D \text { blank }} \times 100$

\section{Clonogenic assay}

Cells were grown in six-well culture plates 100 cells/well, for a day. The next day, the cells were incubated for $72 \mathrm{~h}$ in $5 \% \mathrm{CO} 2$ at $37^{\circ} \mathrm{C}$ with $1 \mu \mathrm{M}, 10 \mu \mathrm{M}$, and $20 \mu \mathrm{M}$ of $\mathrm{I}_{2}, \mathrm{I}_{3} \mathrm{~K}$, and a combination of both. The reaction was terminated by removing the iodine-containing medium, and the cells were washed twice with cold PBS. The cells were then grown for 12 days in the mediums. They were supplemented with 10\% fetal bovine serum (Invitrogen), $1 \%$ penicillin, $1 \%$ streptomycin, and $1 \%$ amphotericin $B$. The cells were then washed with PBS, fixed with methanol/water (1:1), and then stained with crystal violet. Macroscopic colonies were counted. These experiments were performed twice. The proliferation rate was calculated as the number of cell colonies in plates treated with $\mathrm{I}_{2}, \mathrm{I}_{3} \mathrm{~K}$, and a combination of both compared with those untreated cells.

\section{Statistical analysis}

All experiments were performed in triplicate. Results are presented as means \pm standard deviation. Statistical significance comparing experimental values used non-parametric tests (Kruskal-Wallis and Mann-Whitney test). One-way ANOVA and post-hocBonferroni for the parametric test were performed.

\section{Results}

\section{MDA-MB 231 cell lines}

The averages of the cell proliferation after treatments of $\mathrm{I}_{2}, \mathrm{I}_{3} \mathrm{~K}$, and combination of $\mathrm{I}_{2}-\mathrm{I}_{3} \mathrm{~K}(1 \mu \mathrm{M})$ were $98 \pm 5 \%, 88 \pm 33 \%$, and $110 \pm 3 \%$, respectively, $95 \pm 6 \%$, $80 \pm 6 \%$, and $79 \pm 7 \%$ respectively, and $55 \pm 8 \%, 53 \pm 8 \%$, and $47 \pm 7 \%$, respectively, as shown in Table 1 . The cell 


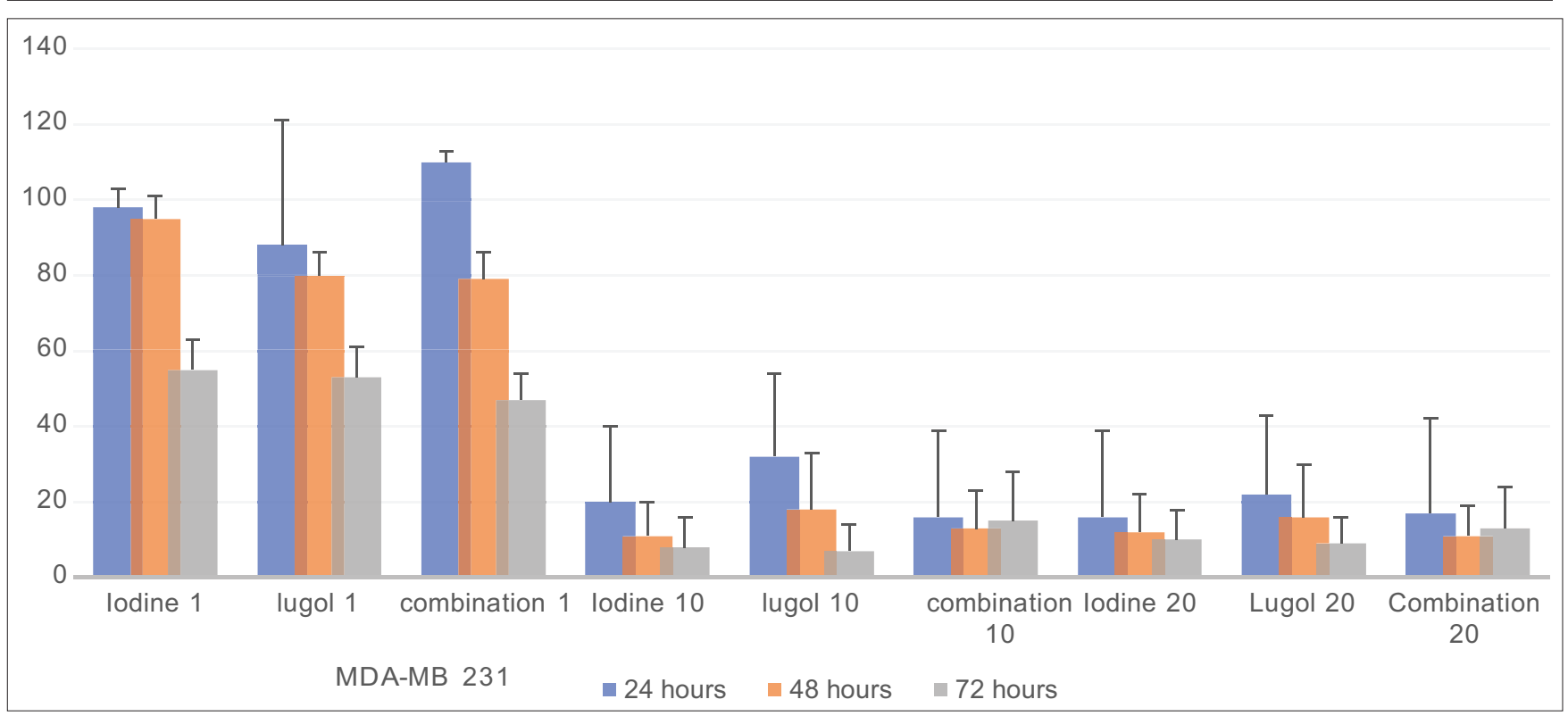

Figure 1: MDA-MD 231 cell proliferation rate of various treatments of iodine, Lugol, and combination of both for 24, 48, and $72 \mathrm{~h}$. The proliferation rates reduced significantly with treatments $10 \mu \mathrm{M}$ and $20 \mu \mathrm{M}$ compared to $1 \mu \mathrm{M}(p=0.001, p=0.001$, and $p=0.001)$, respectively.

Table 1: MDA-MB231 cells proliferation rate after 1, 10, and $20 \mu \mathrm{M}$ of $\mathrm{I}_{2}, \mathrm{I}_{3} \mathrm{~K}$ and $\mathrm{I} \mathrm{I}_{2}-\mathrm{I}_{3} \mathrm{~K}$ combination

\begin{tabular}{|c|c|c|c|c|}
\hline $\begin{array}{l}\text { MDA-MB } 231 \\
(\%)\end{array}$ & $\begin{array}{l}\text { Cell proliferation } \\
\text { Means } \pm \text { SD }(\%) \\
24 \mathrm{~h}\end{array}$ & $\begin{array}{l}\text { Cell proliferation } \\
\text { Means } \pm \mathrm{SD}(\%) \\
48 \mathrm{~h}\end{array}$ & $\begin{array}{l}\text { Cell proliferation } \\
\text { Means } \pm \text { SD }(\%) \\
72 \mathrm{~h}\end{array}$ & $p$ \\
\hline \multicolumn{5}{|l|}{$T_{2}$} \\
\hline 1 & $98 \pm 5$ & $95 \pm 6$ & $55 \pm 8$ & 0.001 \\
\hline 10 & $20 \pm 20$ & $11 \pm 9$ & $8 \pm 8$ & 0.590 \\
\hline 20 & $16 \pm 23$ & $12 \pm 10$ & $10 \pm 10$ & 0.940 \\
\hline \multirow{2}{*}{\multicolumn{5}{|c|}{$\mathrm{I}_{3} \mathrm{~K}$}} \\
\hline & & & & \\
\hline 1 & $88 \pm 33$ & $80 \pm 6$ & $53 \pm 8$ & 0.170 \\
\hline 10 & $32 \pm 22$ & $18 \pm 15$ & $7 \pm 7$ & 0.360 \\
\hline 20 & $22 \pm 21$ & $16 \pm 14$ & $9 \pm 7$ & 0.730 \\
\hline $\mathrm{p}$ & 0.079 & 0.061 & 0.055 & \\
\hline \multicolumn{5}{|l|}{$\mathrm{I}_{2}+\mathrm{I}_{3} \mathrm{~K}$} \\
\hline 1 & $110 \pm 3$ & $79 \pm 7$ & $47 \pm 7$ & 0.490 \\
\hline 10 & $16 \pm 23$ & $13 \pm 10$ & $15 \pm 13$ & 0.449 \\
\hline 20 & $17 \pm 25$ & $11 \pm 18$ & $13 \pm 16$ & 0.709 \\
\hline$p$ & 0.066 & 0.055 & 0.066 & \\
\hline
\end{tabular}

proliferation rate of MDA-MB 231 cells was reduced significantly by treatment $\mathrm{I}_{2}, \mathrm{I}_{3} \mathrm{~K}$, and combination of both with $p=0.040, p=0.001$, and $p=0.001$, respectively, as shown in Figure 1. Treatment doses of $10 \mu \mathrm{M}$ and $20 \mu \mathrm{M}$ reduced cell proliferation significantly compared to the dose of $1 \mu \mathrm{M}$ with $p=0.001$ and $p=0.001$.

The antiproliferation rate of $\mathrm{I}_{2}, \mathrm{I}_{3} \mathrm{~K}$, and combination of both for 24,48 , and $72 \mathrm{~h}$ treatment, not differ significantly. The treatment combination did not show different results compared to $\mathrm{I}_{2}, \mathrm{I}_{3} \mathrm{~K}$ alone $p=0.177, p=0.066$, and $p=0.329$.

\section{MCF7 cell lines}

The averages of the cell proliferation after treatments of $\mathrm{I}_{2}, \mathrm{I}_{3} \mathrm{~K}$, and combination of $\mathrm{I}_{2}$, and $\mathrm{I}_{3} \mathrm{~K}$ $(1 \mathrm{mM})$ for $24 \mathrm{~h}$ were $60 \pm 7 \%, 140 \pm 56 \%$, and 273 $\pm 106 \%$, respectively, for $48 \mathrm{~h}$ were $66 \pm 31 \%, 114 \pm$ $98 \%$, and $103 \pm 13 \%$, respectively, and for $72 \mathrm{~h}$ were $27 \pm 17 \%, 162 \pm 22 \%$, and $105 \pm 11 \%$, respectively, as showed in Table 2. lodine treatment showed a reduced
Table 2: MCF7 cells line proliferation rate after 1, 10, and $20 \mu \mathrm{M}$ of $\mathrm{I}_{2}, \mathrm{I}_{3} \mathrm{~K}$ and $\mathrm{a} \mathrm{I}_{2}-\mathrm{I}_{3} \mathrm{~K}$ combination

\begin{tabular}{|c|c|c|c|c|}
\hline MCF7 (\%) & $\begin{array}{l}\text { Cell proliferation } \\
\text { Means } \pm \text { SD }(\%) \\
24 \mathrm{~h}\end{array}$ & $\begin{array}{l}\text { Cell proliferation } \\
\text { Means } \pm \mathrm{SD}(\%) \\
48 \mathrm{~h}\end{array}$ & $\begin{array}{l}\text { Cell proliferation } \\
\text { Means } \pm \text { SD }(\%) \\
72 \mathrm{~h}\end{array}$ & $p$ \\
\hline \multicolumn{5}{|l|}{$\mathrm{I}_{2}$} \\
\hline 1 & $60 \pm 7$ & $66 \pm 31$ & $27 \pm 17$ & 0.144 \\
\hline 10 & $52 \pm 6$ & $16 \pm 11$ & $17 \pm 9$ & 0.010 \\
\hline 20 & $28 \pm 21$ & $25 \pm 19$ & $6 \pm 4$ & 0.280 \\
\hline $\mathrm{p}$ & 0.113 & 0.099 & 0.177 & \\
\hline \multicolumn{5}{|l|}{$\mathrm{I}_{3} \mathrm{~K}$} \\
\hline 1 & $140 \pm 56$ & $114 \pm 98$ & $162 \pm 22$ & 0.689 \\
\hline 10 & $120 \pm 34$ & $30 \pm 16$ & $26 \pm 10$ & 0.001 \\
\hline 20 & $36 \pm 24$ & $6 \pm 6$ & $12 \pm 10$ & 0.154 \\
\hline $\mathrm{p}$ & 0.055 & 0.042 & 0.001 & \\
\hline \multicolumn{5}{|l|}{$\mathrm{I}_{2}+\mathrm{I}_{3} \mathrm{~K}$} \\
\hline 1 & $273 \pm 106$ & $103 \pm 13$ & $105 \pm 11$ & 0.021 \\
\hline 10 & $115 \pm 28$ & $33 \pm 9$ & $21 \pm 9$ & 0.065 \\
\hline 20 & $32 \pm 22$ & $14 \pm 6$ & $14 \pm 11$ & 0.275 \\
\hline $\mathrm{p}$ & 0.010 & 0.000 & 0.000 & \\
\hline
\end{tabular}

cell proliferation rate of MCF7, and the effect did not make a significant difference between those doses, as shown in Figure 2. Treatment of Lugol $10 \mu \mathrm{M}$ and $20 \mu \mathrm{M}$ reduced cell proliferation significantly compared to Lugol $1 \mu \mathrm{M}$, with $p=0.001$ and $p=0.001$, respectively. The combination of $\mathrm{I}_{2}$ and $\mathrm{I}_{3} \mathrm{~K} 10 \mu \mathrm{M}$ and $20 \mu \mathrm{M}$ reduced cell proliferation significantly compare to $1 \mu \mathrm{M}$ dose, with $p=0.001$ and $p=0.010$, respectively. There is no significantly different effect on cell proliferation between combination treatments of $\mathrm{I}_{2}$ and $\mathrm{I}_{3} \mathrm{~K}$ of $10 \mu \mathrm{M}$ with $20 \mu \mathrm{M}$.

\section{SKBR3 cell lines}

The averages of the cell proliferation after treatments of $\mathrm{I}_{2}, \mathrm{I}_{3} \mathrm{~K}$, and combination of $\mathrm{I}_{2}$ and $\mathrm{I}_{3} \mathrm{~K}$ $(1 \mu \mathrm{M})$ for $24 \mathrm{~h}$ were $29 \pm 10 \%, 96 \pm 20 \%$, and $93 \pm$ $23 \%$, respectively, for $48 \mathrm{~h}$ were $25 \pm 21 \%, 141 \pm 75 \%$, and $111 \pm 70 \%$, respectively, and for $72 \mathrm{~h}$ were $27 \pm$ $17 \%, 335 \pm 216 \%, 242 \pm 80 \%$, respectively, as shown in Table 3. lodine reduced proliferation cell up to $85 \%$. The antiproliferative effect did not differ between $\mathrm{I}_{2}$ treatment doses, as shown in Figure 3. However, the 


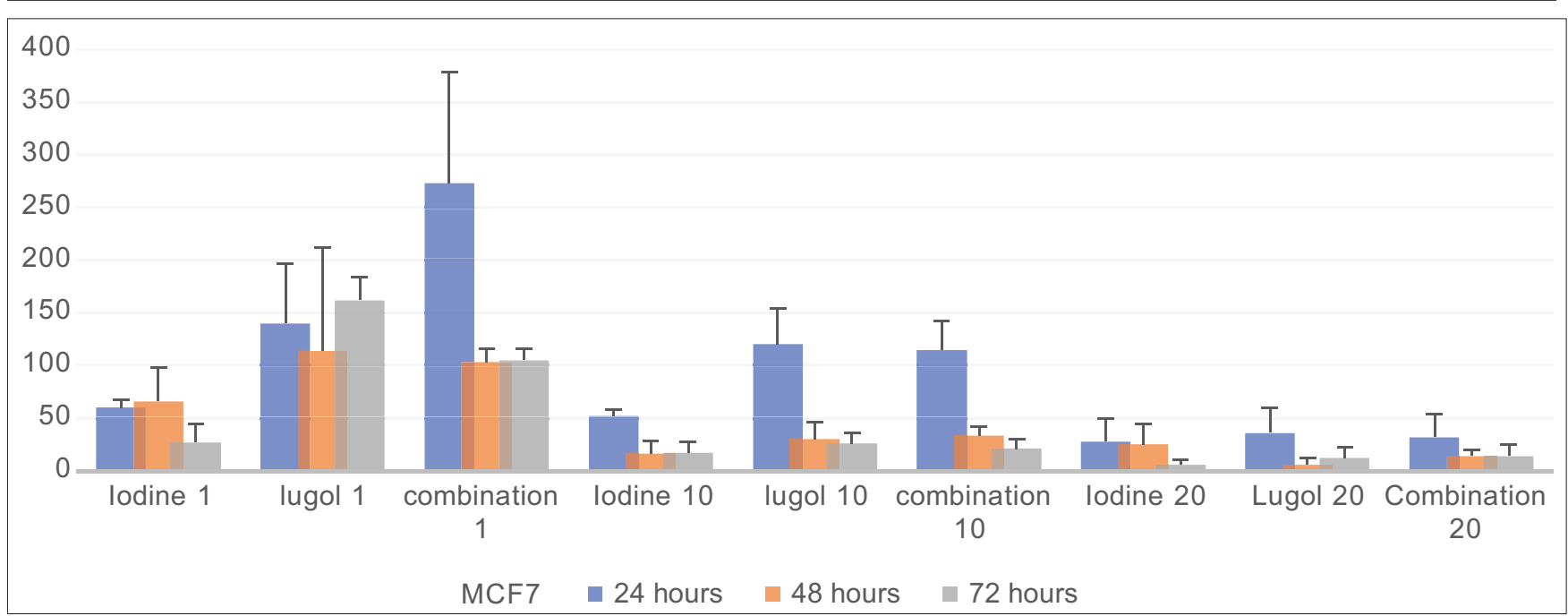

Figure 2: MCF7 cell proliferation rate of various iodine, Lugol treatments, and a combination of both for 24,48 , and $72 \mathrm{~h}$. lodine treatment doses reduced cell proliferation did not depend on the dose. Lugol and a combination of $\mathrm{I}_{2}$ and $\mathrm{I}_{3} \mathrm{~K}(10 \mu \mathrm{M})$ showed an antiproliferative effect after 48 and $72 \mathrm{~h}$ of treatments $p=0.010$ and $p=0.001$, respectively

Table 3: SKBR3 cells proliferation rate after 1,10 , and $20 \mu \mathrm{M}$ of $\mathrm{I}_{2}, \mathrm{I}_{3} \mathrm{~K}$ and combination of $\mathrm{I}_{2}-\mathrm{I}_{3} \mathrm{~K}$ treatments

\begin{tabular}{cllll}
\hline SKBR3 (\%) & $\begin{array}{l}\text { Cell proliferation } \\
\text { Means } \pm \text { SD (\%) } \\
\end{array}$ & $\begin{array}{l}\text { Cell proliferation } \\
\text { Means } \pm \text { SD }(\%)\end{array}$ & $\begin{array}{l}\text { Cell proliferation } \\
\text { Means } \pm \text { SD }(\%)\end{array}$ & $\mathrm{p}$ \\
& $24 \mathrm{~h}$ & $\mathrm{~h}$ & \\
\hline $\mathrm{I}_{2}$ & $29 \pm 10$ & $25 \pm 21$ & $27 \pm 17$ & 0.220 \\
1 & $15 \pm 3$ & $17 \pm 15$ & $15 \pm 10$ & 0.988 \\
10 & $16 \pm 16$ & $19 \pm 14$ & $24 \pm 15$ & 0.226 \\
20 & 0.236 & 0.381 & 0.413 & \\
$\mathrm{p}$ & & & & \\
$\mathrm{I}_{3} \mathrm{~K}$ & $96 \pm 20$ & $141 \pm 75$ & $335 \pm 216$ & 0.148 \\
1 & $16 \pm 6$ & $15 \pm 10$ & $11 \pm 10$ & 0.560 \\
10 & $6 \pm 6$ & $24 \pm 18$ & $10 \pm 6$ & \\
20 & 0.001 & 0.069 & 0.006 & \\
$\mathrm{p}$ & & & & 0.23 \\
$\mathrm{I}_{2}+\mathrm{I}_{3} \mathrm{~K}$ & $93 \pm 23$ & $111 \pm 70$ & $242 \pm 80$ & 0.94 \\
1 & $11 \pm 8$ & $17 \pm 12$ & $16 \pm 14$ & \\
10 & $14 \pm 12$ & $21 \pm 10$ & $25 \pm 11$ & 0.83 \\
20 & 0.001 & 0.215 & 0.008 & \\
$\mathrm{p}$ & & & &
\end{tabular}

treatment effect of $\mathrm{I}_{3} \mathrm{~K}$ and a combination of $\mathrm{I}_{2}$ and $\mathrm{I}_{3} \mathrm{~K}$ depends on the dose, with $p=0.001$ and $p=0.001$ for $24 \mathrm{~h}$, respectively, and $p=0.006$ and $p=0.008$ for $72 \mathrm{~h}$, respectively. The combination of $\mathrm{I}_{2}$ and $\mathrm{I}_{3} \mathrm{~K}(1 \mu \mathrm{M})$ had no different results with $\mathrm{I}_{3} \mathrm{~K}(1 \mu \mathrm{M})$ alone, with $\mathrm{p}=0.623$.

\section{Clonogenic result}

lodine treatment in varying doses discontinues the cell proliferation, as shown in Table 4 and Figure 4. Even though $\mathrm{I}_{3} \mathrm{~K} 1 \mu \mathrm{M}$ dose did not affect in the slowing of cell proliferation, but $10 \mu \mathrm{M}$ and $20 \mu \mathrm{M}$ doses suppressed cell proliferation.

\section{Discussion}

In thyroid cell and lactating mammary gland, iodide transport is facilitated by NIS [6], [22]. lodide excess induces apoptosis in thyrocytes, and the effect depends on thyroid peroxidase [3]. On the
Table 4: The clonogenic assay results in MDA-MB 231, SKBR3, and MCF7 cell lines after $1 \mu \mathrm{M}, 10 \mu \mathrm{M}$, and $20 \mu \mathrm{M}$ of $\mathrm{I}_{2}, \mathrm{I}_{3} \mathrm{~K}$ treatments

\begin{tabular}{llll}
\hline Doses (\%) & MDA-MB 231 & SKBR3 & MCF7 \\
\hline $\mathrm{I}_{2}{ }_{1}$ & 0 & 0 & 0 \\
10 & 0 & 0 & 0 \\
20 & 0 & 0 & 0 \\
$\mathrm{I}_{3} \mathrm{~K}$ & & & \\
1 & $230 \pm 25(62.8 \%)$ & $208 \pm 34(39.8 \%)$ & $284 \pm 51(71 \%)$ \\
10 & 0 & 0 & 0 \\
20 & 0 & 0 & 0 \\
Control & $366 \pm 8.5$ & $523 \pm 28.3$ & $400 \pm 28.3$ \\
\hline
\end{tabular}

other hand, non-lactating mammary gland has a low level of peroxidase. The condition does not provide the environment for iodide organification. However, $\mathrm{I}_{2}$ can be utilized without sodium iodide symporter and peroxidase [19], [23]. I treatment in benign breast cancer has been found to reduce tumor size and symptoms, but not I' treatment [6]. lodide is preferentially taken up and retained in the thyroid and lactating mammary glands, but the pituitary, ovary, and non-lactating breast glands, $\mathrm{I}_{2}$ are taken up more readily than I' [6], [22].

lodine in breast tissue was explained by in vitro studies that $\mathrm{I}_{2}$ is taken up through diffusion, then incorporated into iodolipids and nuclear components, then exert antiproliferative and apoptotic properties [3], [19], [24]. Previous studies have reported that the antiproliferative effects of $I_{2}$ are through MMP destruction that directly results in apoptosis. MMP is needed for mitochondrial functions such as ATP production, metabolite transport regulation, and protein import. The mitochondrial intermembrane space contains several proteins that induce apoptosis through cytochrome $\mathrm{c}$ induction or activation of a caspase-independent apoptotic death program [3], [8], [9], [25]. Furthermore, iodine's antiproliferative effect can occur through iodolipid formation, 6-IL, or alpha-iodohexane canal, and the activation of PPAR $\gamma$ interaction through increased BAX, caspases 3, 7, p53, and p21 [1], [3], [21], [25]. 


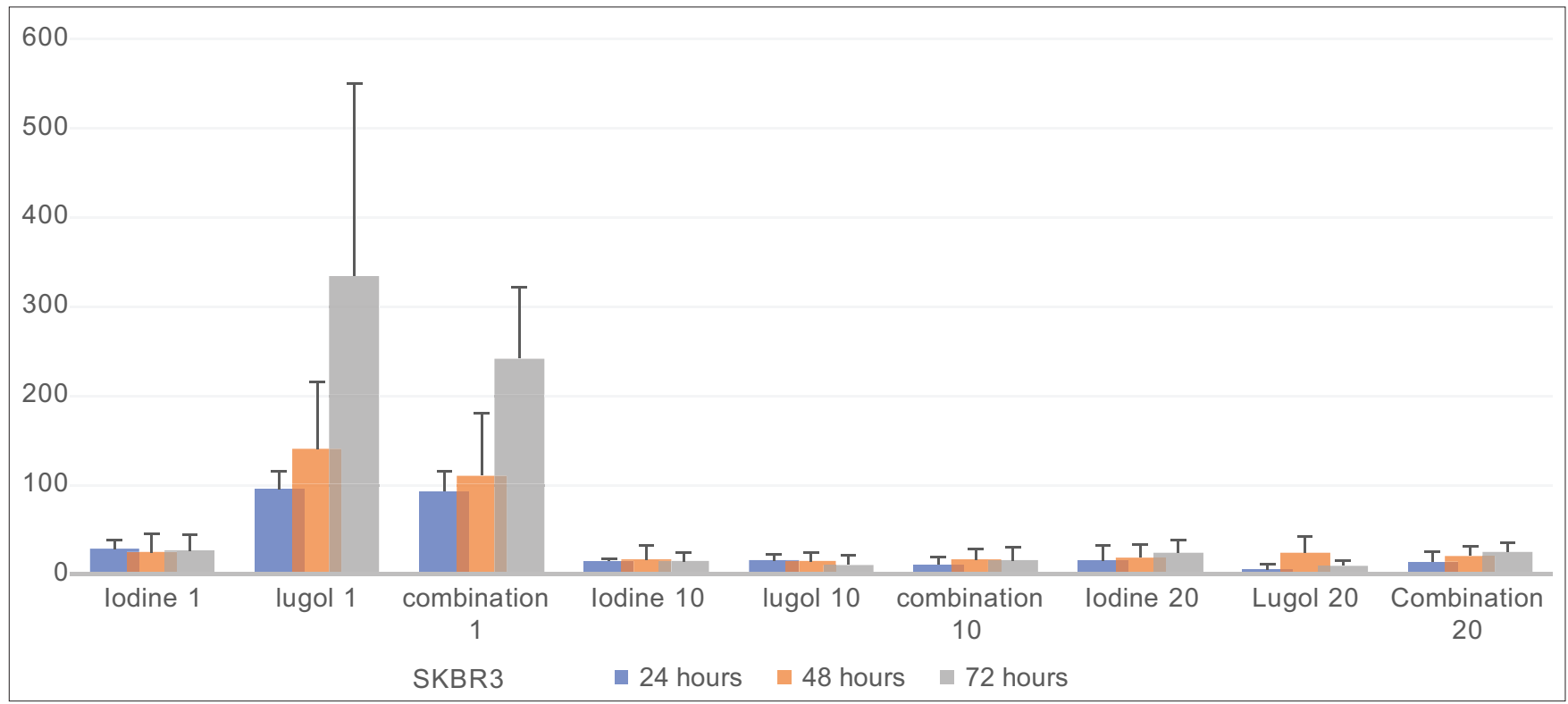

Figure 3: SKBR3 cell proliferation rate of the various treatment doses of iodine, Lugol, and a $\mathrm{I}_{2}-\mathrm{I}_{3} \mathrm{~K}$ combination for 24,48 , and $72 \mathrm{~h}$. Iodine reduced the cell proliferation did not depend on the dose. Lugol and combination iodine and Lugol showed reduced cell proliferation with $10 \mu \mathrm{M}$ and $20 \mu \mathrm{M}$ with $p=0.001$ and $p=0.001$, respectively

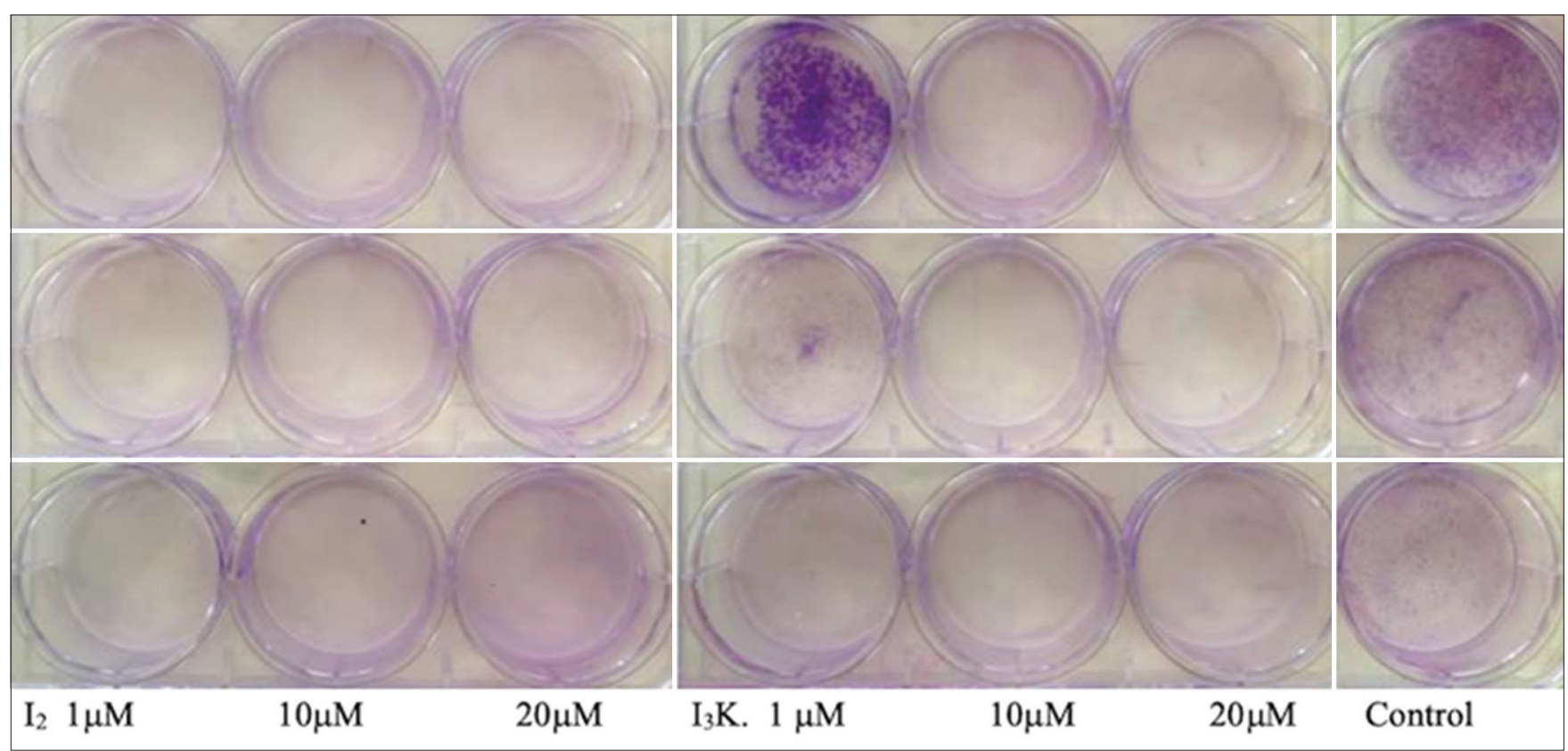

Figure 4: Clonogenic assay results, as shown on MCF7 (top), MDA-MB231 (middle), and SKBR3 (below). From left to right are results of the

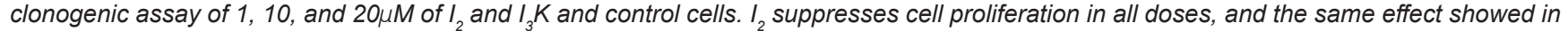
$10 \mu \mathrm{M}$ and $20 \mu \mathrm{M}$ of $\mathrm{I}_{3} \mathrm{~K}$

Recently, a study has reported that $\mathrm{I}_{2}$ treatment did not have an antiproliferative effect in MDA-MB 231 cells [4]. This study found that the proliferation MDA-MB 231 cell discontinued by $\mathrm{I}_{2}$ treatment, as shown in Figures 1 and 4 . The low dose of $\mathrm{I}_{3} \mathrm{~K}(1 \mu \mathrm{M})$ showed a limitation of the MDA-MB 231 cells' antiproliferation effect. However, $10 \mu \mathrm{M}$ and $20 \mu \mathrm{M}$ of $\mathrm{I}_{3} \mathrm{~K}$ and a combination of $\mathrm{I}_{2}$ and $\mathrm{I}_{3} \mathrm{~K}$ reduced cell proliferation significantly with $\mathrm{p}<0.05$ (Table 1). A combination of treatments did not show an increasing effect when it is compared with $\mathrm{I}_{2}$ and $\mathrm{I}_{3} \mathrm{~K}$ alone. $\mathrm{I}_{3} \mathrm{~K}$ reduces cell proliferation effect in this study, in line with a study by Rösner et al. [6]. The clonogenic result showed that $I_{2}$ doses inhibited cell proliferation and $\mathrm{I}_{3} \mathrm{~K}(10 \mu \mathrm{M}$ and $20 \mu \mathrm{M}$ ), as shown in Figure 4. However, the mechanism of iodine induces apoptosis in MDA-MB 231 has yet to be elucidated.

Meanwhile, $\mathrm{I}_{2}$ inhibited the proliferation of MCF7 cells was not a dose-dependent manner (Table 2). The treatment reduced cell proliferation by up to $94 \%$. This finding has a similar result with previous studies [3], [5], [26]. Furthermore, a study 
reported that $\mathrm{I}_{2}$ treatment was found to inhibit MCF7 cell growth, that even more effective than in MDA-MB 231 cells [1], [21]. In this study, $I_{2}$ treatments show similar effective in MCF7, MDA-MB 231, and SKBR3 cells from the clonogenic result. $\mathrm{I}_{2}$ treatment increases the apoptotic rate and PPAR $\gamma$ expression, leading to a decrease in proliferation and dissipating the estrogen receptor alpha's translocation to the nucleus [3]. As MCF7 and MDA-MB 231 cells express PPAR $\gamma$ receptors, it can be hypothesized that the antiproliferation mechanism of $\mathrm{I}_{2}$ in both cell lines is likely to be through iodinePPAR $\gamma$ receptor interactions [21], [27]. Further studies are needed to explore it. Furthermore, $\mathrm{I}_{3} \mathrm{~K}$ treatments showed an antiproliferation effect on MCF7 exerts a dose-dependent manner. Nevertheless, a combination of $\mathrm{I}_{2}$ and $\mathrm{I}_{3} \mathrm{~K}$ inhibited cell proliferation did not increase significantly compared with $\mathrm{I}_{3} \mathrm{~K}$ treatment alone, as shown in Table 2 . The clonogenic result showed that $\mathrm{I}_{3} \mathrm{~K}$ (10 $\mu \mathrm{M}$ and $20 \mu \mathrm{M}$ ) effectively to stop cell proliferation (Figure 4).

SKBR3 cells do express NIS and showed that they could take radioiodine [28], [29]. In this study, $I_{2}$ and $\mathrm{I}_{3} \mathrm{~K}$ showed an antiproliferative effect, as shown in Table 3. The iodine effect did not change by a different dose. However, antiproliferative effect of $\mathrm{I}_{3} \mathrm{~K}$ and the combination of $\mathrm{I}_{2}$ and $\mathrm{I}_{3} \mathrm{~K}$ tend to increase with higher doses (Table 3 ). The clonogenic result showed $\mathrm{I}_{3} \mathrm{~K}$ (10 $\mu \mathrm{M}$ and $20 \mu \mathrm{M}$ ) effectively to discontinued SKBR3 cell proliferation (Table 4). Further investigations are needed to elaborate on the mechanism of the apoptotic process of iodine exposure in breast cancer.

\section{Conclusion}

lodine treatment was sufficient to discontinue cell proliferation of MCF7, MDA-MB231, and SKBR3 cells. The antiproliferative effect of $\mathrm{I}_{3} \mathrm{~K}$ shows in $\mathrm{a}$ dose-dependent manner. Breast cancer cell lines, representing subtypes of luminal A, HER2+, and triple-negative, show an excellent response to iodine treatments. Further studies are needed to investigate the effective dose of iodine to breast cancer subtypes in vivo and the effect toward the normal cell. This finding opens the opportunity of using iodine for breast cancer prevention as well as an alternative therapy.

\section{Acknowledgments}

Thanks to Universitas Andalas for the research grant No: 57/UN.16.17/PP.PGB/LPPM/2018. Thanks to Dr. Ahmad Faried, Ph.D., who has gifted MCF7 cell lines and Dr. med. Muhammad Hasan MD., who has gifted
MDA-MB 231 cell lines from the Faculty of Medicine, Universitas Padjadjaran, Bandung. Indonesia.

\section{Ethical clearance}

The subject in this research was cell lines; the authors did not have any contact with human or animal subjects, hence, not applicable.

\section{References}

1. Aceves C, García-Solís $P$, Arroyo-Helguera O, Vega-Riveroll L, Delgado G, Anguiano B. Antineoplastic effect of iodine in mammary cancer: Participation of 6-iodolactone (6-IL) and peroxisome proliferator-activated receptors (PPAR). Mol Cancer. 2009;8:33. https://doi.org/10.1186/1476-4598-8-33 PMid:19500378

2. Aceves C, Anguiano B. Is iodine an antioxidant and antiproliferative agent for the mammary and prostate glands. In: Comprehensive Handbook of lodine: Nutritional, Endocrine and Pathological Aspects. San Diego, CA: Elsevier; 2009. p. 249-57. https://doi.org/10.1016/b978-0-12-374135-6.00026-1

3. Aceves C, Anguiano B, Delgado G. The extrathyronine actions of iodine as antioxidant, apoptotic, and differentiation factor in various tissues. Thyroid. 2013;23(8):938-46. https://doi. org/10.1089/thy.2012.0579

\section{PMid:23607319}

4. Shrivastava A, Tiwari M, Sinha RA, Kumar A, Balapure AK, Bajpai VK, et al. Molecular iodine induces caspaseindependent apoptosis in human breast carcinoma cells involving the mitochondria-mediated pathway. $\mathrm{J}$ Biol Chem. 2006;281(28):19762-71. https://doi.org/10.1074/jbc. m600746200

PMid:16679319

5. Elio Torremante $\mathrm{P}$, Rosner $\mathrm{H}$. Antiproliferative effects of molecular iodine in cancers. Curr Chem Biol. 2011;5(3):168-76. https://doi.org/10.2174/187231311796764987

6. Rösner H, Möller W, Groebner S, Torremante P. Antiproliferative/ cytotoxic effects of molecular iodine, povidone-iodine and Lugol's solution in different human carcinoma cell lines. Oncol Lett. 2016;12(3):2159-62. https://doi.org/10.3892/ol.2016.4811 PMid:27602156

7. Kessler J. Are there side effects when using supraphysiological levels of iodine in treatment regimens. In: Comprehensive Handbook of lodine: Nutritional, Endocrine and Pathological Aspects. San Diego, CA: Academic Press; 2009. p. 801-10. https://doi.org/10.1016/b978-0-12-374135-6.00082-0

8. Anguiano B, Aceves C. lodine in mammary and prostate pathologies. Curr Chem Biol. 2011;5(3):177-82. https://doi. org/10.2174/187231311796765049

9. Singh P, Godbole M, Rao G, Annarao S, Mitra K, Roy R, et al. Inhibition of autophagy stimulate molecular iodine-induced apoptosis in hormone independent breast tumors. Biochem Biophys Res Commun. 2011;415(1):181-6. https://doi. org/10.1016/j.bbrc.2011.10.054

PMid:22027149

10. Dagenais GR, Leong DP, Rangarajan S, Lanas F, Lopez-Jaramillo P, Gupta R, et al. Variations in common diseases, hospital admissions, and deaths in middle-aged adults in 21 countries from five continents (PURE): A prospective cohort study. Lancet. 2020;395(10226):785-94. https://doi. 
org/10.1016/s0140-6736(19)32007-0

11. Elliyanti A. AIP Conference Proceedings. Maryland: AIP Publishing LLC; 2019.

12. Bray F, Ferlay J, Soerjomataram I, Siegel RL, Torre LA, Jemal A. Global cancer statistics 2018: GLOBOCAN estimates of incidence and mortality worldwide for 36 cancers in 185 countries. CA Cancer J Clin. 2018;68(6):394-424. https://doi. org/10.3322/caac.21492 PMid:30207593

13. DeSantis CE, Ma J, Gaudet MM, Newman LA, Miller KD, Goding Sauer A, et al. Breast cancer statistics, 2019. CA Cancer J Clin. 2019;69(6):438-51. https://doi.org/10.3322/caac.21583 PMid:31577379

14. Nakamura K, Okada E, Ukawa S, Hirata M, Nagai A, Yamagata $\mathrm{A}$, et al. Characteristics and prognosis of Japanese female breast cancer patients: The BioBank Japan project. J Epidemiol. 2017;27(3S):S58-64. PMid:28223083

15. Borin TF, Angara K, Rashid MH, Achyut BR, Arbab AS. Arachidonic acid metabolite as a novel therapeutic target in breast cancer metastasis. Int J Mol Sci. 2017;18(12):2661. https://doi.org/10.3390/ijms18122661 PMid:29292756

16. Haque M, Desai KV. Pathways to endocrine therapy resistance in breast cancer. Front Endocrinol (Lausanne). 2019;10:573.

PMid:31496995

17. Elliyanti A, Rusnita D, Afriani N, Susanto YD, Susilo VY Setiyowati $\mathrm{S}$, et al. Analysis natrium iodide symporter expression in breast cancer subtypes for radioiodine therapy response. Nucl Med Mol Imaging. 2020;54(1):35-42. https://doi. org/10.1007/s13139-019-00632-8

PMid:32206129

18. Langlands FE, Horgan K, Dodwell DD, Smith L. Breast cancer subtypes: Response to radiotherapy and potential radiosensitisation. $\mathrm{Br} J$ Radiol. 2013;86(1023):20120601. https://doi.org/10.1259/bjr.20120601

19. Aceves C, Anguiano B, Delgado G. Is iodine a gatekeeper of the integrity of the mammary gland? J Mammary Gland Biol Neoplasia. 2005;10(2):189-96. https://doi.org/10.1007/ s10911-005-5401-5 PMid: 16025225

20. Arroyo-Helguera O, Anguiano B, Delgado G, Aceves C. Uptake and antiproliferative effect of molecular iodine in the MCF-7 breast cancer cell line. Endocr Relat Cancer. 2006;13(4):114758. https://doi.org/10.1677/erc.1.01250

PMid: 17158760

21. Bontempo A, Ugalde-Villanueva B, DelgadoGonzález E, Rodríguez ÁL, Aceves C. Molecular iodine impairs chemoresistance mechanisms, enhances doxorubicin retention and induces downregulation of the CD44+/CD24+ and E-cadherin+/vimentin+ subpopulations in MCF-7 cells resistant to low doses of doxorubicin. Oncol Rep. 2017;38(5):2867-76. https://doi.org/10.3892/or.2017.5934

PMid:28901484

22. Micali S, Bulotta S, Puppin C, Territo A, Navarra M, Bianchi G, et al. Sodium iodide symporter (NIS) in extrathyroidal malignancies: Focus on breast and urological cancer. BMC Cancer. 2014;14:303. https://doi.org/10.1186/1471-2407-14-303 PMid:24884806

23. Godlewska M, Arczewska KD, Rudzińska M, Łyczkowska A, Krasuska W, Hanusek K, et al. Thyroid peroxidase (TPO) expressed in thyroid and breast tissues shows similar antigenic properties. PLoS One. 2017;12(6):e0179066. https://doi. org/10.1371/journal.pone. 0179066 PMid:28575127

24. Arroyo-Helguera O, Rojas E, Delgado G, Aceves C. Signaling pathways involved in the antiproliferative effect of molecular iodine in normal and tumoral breast cells: Evidence that 6-iodolactone mediates apoptotic effects. Endocr Relat Cancer. 2008;15(4):1003-11. https://doi.org/10.1677/erc-08-0125 PMid: 18827038

25. Nava-Villalba M, Nuñez-Anita RE, Bontempo A, Aceves C Activation of peroxisome proliferator-activated receptor gamma is crucial for antitumoral effects of 6-iodolactone. Mol Cancer. 2015;14:168. https://doi.org/10.1186/s12943-015-0436-8 PMid:26376791

26. Rösner H, Torremante P, Möller W, Gärtner R. Antiproliferative/ cytotoxic activity of molecular iodine and iodolactones in various human carcinoma cell lines. No interfering with EGF-signaling, but evidence for apoptosis. Exp Clin Endocrinol Diabetes. 2010;118(7):410-9. https://doi.org/10.1055/s-0029-1225615 PMid:19802778

27. Suchanek KM, May FJ, Robinson JA, Lee WJ, Holman NA, Monteith GR, et al. Peroxisome proliferator-activated receptor alpha in the human breast cancer cell lines MCF-7 and MDA-MB-231. Mol Carcinog. 2002;34(4):165-71. https://doi. org/10.1002/mc.10061

PMid: 12203367

28. Elliyanti A, Eka Putra A, Sribudiani $\mathrm{Y}$, Noormartany $\mathrm{N}$ Masjhur JS, Achmad TH, et al. Epidermal growth factor and adenosine triphosphate induce natrium iodide symporter expression in breast cancer cell lines. Open Access Maced J Med Sci. 2019;7(13):2088-92. https://doi.org/10.3889/ oamjms.2019.620 PMid:31456831

29. Elliyanti A, Susilo VY, Setiyowati S, Ramli M, Masjhur JS, Achmad TH. Uptake and cytotoxicity characterization of radioiodine in MCF-7 and SKBR3 breast cancer cell lines. Atom Indones. 2016;42:145-9. https://doi.org/10.17146/aij.2016.586 